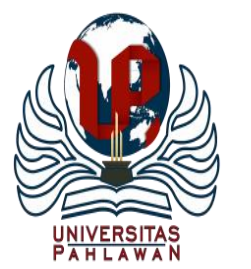

Edukatif : Jurnal Ilmu Pendidikan Volume 3 Nomor 1 Tahun 2021 Halm 213-219 EDUKATIF: JURNAL ILMU PENDIDIKAN

Research \& Learning in Education

https:/ledukatif.org/index.php/edukatif/index

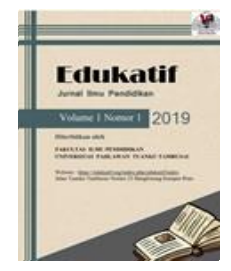

\title{
Meningkatkan Kreativitas Belajar Siswa Melalui Metode Pembelajaran Learning Start With A Question di Sekolah Dasar
}

\author{
Kamarudin $^{1 凶}$, Yana $^{2}$ \\ Universitas Muhammadiyah Buton, Indonesia ${ }^{1,2}$ \\ E-mail : akamarudin1453@gmail.com ${ }^{1}$, yana.yana21@ gmail.com ${ }^{2}$
}

\begin{abstract}
Abstrak
Pendidkan merupakan hal yang paling penting dalam kehidupan manusia untuk mengembangkan diri dalam duina pendidkan sekolah dasar, dengan demikian manusia bisa memiliki keilmuan dan pengetahuan. Agar mencapai hal tersebut, guru harus peran untuk mendorong siswa dengan membangkitkan semangat peserta didik agar mau berlatih sebab siswa merupakan subjek utamanya dalam proses pembelajaran. Tujuan penelitian ini untuk meningkatkan kreativitas belajar siswa melalui metode pembelajaran Learning Start With A Question pada pelajaran Pendidikan Kewarganegaraan Tema 7 Peristiwa Dalam Kehidupan dikelas V SD Negeri 2 Waha. Metode penelitian ini menggunakan metode penelitan tindakan kelas. Hasil penelitian penerapan metode pembelajaran Learning Start With A Question untuk meningkatkan kreativitas belajarsiswa di kelas V SD Negeri 2 Waha pada mata pelajaran Pendidikan Kewarganegaraan di dapat hasil bahwa kreativitas belajar siswa meningkat yang terjadi pada siklus II. Dimana pada siklus II pertemuan satu tes kreativitas siswa terdapat 16 dengan kategori cukup kreatif dan 2 orang siswa dalam kategori kurang kreatif, sedangkan 4 orang lainnya dalam kategori kreatif dari jumlah 22 orang siswa. Kemudian pada pertemuan kedua, tingkat kreativitas belajar siswa ada 15 orang, siswa masuk kategori kreatif, dan 5 orang siswa dalam kategori sangat kreatif, sedangkan 2 orang lainnya masuk dalam kategori cukup kreatif. Dan pada tes evaluasi belajar siswa pada siklus II meningkat dengan jumlah rata-rata 78,18\%. Oleh karena itu metode pembelajaran Learning Start With A Question dapat meningkatkan kreativitas pada pembelajaran Pendidikan Kewarganegaraan.
\end{abstract}

Kata Kunci: Kreativitas Belajar Siswa, Metode Learning Start With A Question, Pendidikan Kewarganegaraan.

\begin{abstract}
Education is the most important thing in human life for self-development in the world of primary school education. In order to achieve this, the teacher should actively encourage students to practice because students are the main subject in the learning process. The purpose of this study was to increase students' learning creativity through the Learning Start With A Question method in Citizenship Education in the material of Theme of 7 Events in Life in class V SD Negeri 2 Waha. This method used in this research was classroom action research. The results of the research on the application of the Learning Start With A Question learning method to increase students' creativity in class V SD Negeri 2 Waha in the Citizenship Education subject showed that students' learning creativity increased which occurred in cycle II. In students' creativity test in second cycle of meeting one, there were 16 with a fairly creative category and 2 students in the less creative category, while the other 4 were in the creative category out of a total of 22 students. Then at the second meeting of the level of students' learning creativity, there were 15 students in the creative category, and 5 students in the very creative category, while 2 other people were in the fairly creative category. Then in the evaluation of student learning in the second cycle, it increased by an average of $78.18 \%$. Therefore, the Learning Start With A Question method can increase creativity in Citizenship Education learning.
\end{abstract}

Keywords: Students' Learning Creativity, Learning Method Start With A Question, Citizenship Education.

Copyright (c) 2021 Kamarudin, Yana

$\triangle$ Corresponding author

Email : akamarudin1453@gmail.com

DOI : https://doi.org/10.31004/edukatif.v3i1.284

ISSN 2656-8063 (Media Cetak)

ISSN 2656-8071 (Media Online)

Edukatif : Jurnal Ilmu Pendidikan Vol 3 No 1 Tahun 2021 p-ISSN 2656-8063 e-ISSN 2656-8071 


\section{Meningkatkan Kreativitas Belajar Siswa Melalui Metode Pembelajaran Learning Start With A Question}

di Sekolah Dasar - Kamarudin, Yana

DOI: https://doi.org/10.31004/edukatif.v3i1.284

\section{PENDAHULUAN}

Pendidikan merupakan proses belajar juga bisa diartikan satu proses yang sifatnya positif yang memperlihatkan adanya sebuah perubahan hingga pada tahap akhir bisa mendapatkan kecakapan, keterampilan dan pemahaman baru yang didapatkan dari pembelajaran dan pengalaman. Pembelajaran secara harfia diarti sebagai proses belajar. Pembelajaran dapat diartikan sebagai suatu proses memperoleh wawasan dan penambahan pengetahuan dengan menempu serangkaian kegiatan yang dilakukan secara sadar membawa perubahan yang sifatnya positif.

Proses pendidikan tidak terlepas dari peran guru, selaku pelaksana proses belaja rmengajar, juga berperan menjadi fasilitator, dimana harus menciptakan keadaan belajar mengajar yang efesien. Materi pembelajaran tentu selalu dikembangkan dengan baik, dan mampu meningkatkan kemampuan siswa dalam menyimak suatu pelajaran, serta mampu mencapai tujuan dari pendidikan. Belajar Menurut R Gagne (dalam Ahmad Susanto 2016:1), "belajar dapat didefinisikan sebagai suatu proses dimana suatu organisme berubah perilakunya sebagai akibat dari pengalaman" (Kasyadi et al., 2013). Agar mencapai hal tersebut, harus ada pengembangan kemampuaan penerapan model pembelajaran dalam peningkatan peserta didik yang merupakan subjek utamanya dalam belajar. Ciri-ciri umum dalam kegiatan belajar, yang mencakup hal-hal berikut (1) Belajar berlangsung akibat hubungan antara individu dan lingkungannya, (2) Belajar ditandai dengan adanya modifikasi perubahan dari segi moral, kongnitif, verbal, afektif dan tingkah laku, dan (3) Belajar berlangsung karena disengaja atau disadari (Pane \& Darwis Dasopang, 2017).

PPKn mempunyai tujuan yang mampu mennciptakan insan yang bersifat dan berperilaku baik dan bertanggung jawab juga bermanfaat bagi masyarakat, bangsa dan Negara. (Astriani, 2018). Pembelajaran seperti ini tentu berlaku dalam mata pelajaran (Pendidikan Pancasila dan Kewarganegaraan) sangat membutuhkan proses aktivitas pembelajaran peserta didik untuk membantu tercapainya tujuan pembelajaran Pendidikan Pancasiladan Kewarganegaraan serta tercapainya proses pembelajran yang aktif dalam pembelajar siswa. Pendidikan Kewarganegaraan sering dijadikan mandat politik dan alat ideologi rezim. Hingga pada akhirnya, Pendidikan Kewarganegaraan mengikuti keadaan setiap rezim (Bunyamin, 1990; Winataputra, 1999). (Maftuh, 2008).

Pembelajaran yang aktif akan tercipta pembelajaran yang berfokus kepada siswa (student centered). Proses pembelajaran diselenggarakan secara interaksi untuk memotivasi siswa berpartisipasi aktif (Firdaus, 2018). Keberhasilan dalam proses pembelajara disekolah tidak terlepas dari dorongan dan motivafasi guru. Menurut (Rusman, 2013) keberhasilan siswa dalam belajar di sekolah tidak terlepas dari peran seorang guru. Ketika di sekolah guru merupakan faktor terpenting dalam pencapaian keberhasilan dalam belajar.Sehinga dapat mendorong kemampuan siswa untuk berfikir kreatif. Kemampuan berpikir kreatif menurut Johnson (Fajarwati, 2011) ialah kemampuan dimana siswa menghasilkan ide-ide yang baru yang dihasilkan dari pemahaman baru. Sementara itu mengartikan kreativitas sebagai kemampuan untuk mencipta atau berkreasi(Putra et al., 2012).

Sund 1975 berpendapat dalam (Slameto, 2014) bahwa potensi kreatif individu bisa diidentifikasi dengan beberapa karakteristik yaitu: (1) cukup besarhasrat keingin tahuannya, (2) siap menerima pengetahuan baru, (3) panjang akal, (4) hasrat mencari hal baru dan meneliti, (5) menyukai tantangan, (6) tidak puas hanya dengan satu jawaban, (7) aktif dalam melaksanakan tugas serta memiliki dedikasi bergairah, (8) berpikir fleksibel, (9) cenderung memberi jawaban yang memuaskan dan menanggapi pertanyaan yang diajukan, (10) mampu menganalisis banyak hal, (11) memiliki daya absrtaksi yang cukup baik, dan (12) mempunyai kebiasaan membaca informasi yang lebih luas.

Penelitian dengan judul Pengaruh Penerapan Metode Pembelajaran Aktif Tipe Learning Start With A Question Terhadap Keaktifan Belajar Siswa Pada Mata Pelajaran Pendidikan Kewarganegaraan Kelas VIII di 
SMP Negeri 19 Palembang.Dengan demikian maka ada perbedaan antara keaktifan belajar siswa dalam proses pembelajaran PPKn yang diajar menggunakan metode pembelajaran aktif tife learning start with a question lebih baik daripada metode pembelajarn the learning cell di SMP Negeri 19 Palembang.(Istiningsih et al., 2018)

LSQ ( Learning Start With A Question ) adalah: suatu pembelajaran aktif dalam bertanya. Agar siswa dapat aktif bertanya maka siswa diminta untuk mempelajari materi yang akan dipelajarinya dengan bantuan membaca. Dengan membaca maka siswa memiliki gambaran tentang materi yang akan dipelajari, sehingga apabila dalam membaca atau membahas materi tersebut guru mlelakukan suatu proses, sehingga dapat terlihat beberapa persen siswa yang belajar dan yang tidak belajar. (Suharsimi;, 2013)

Dalam proses pembelajaran tentu punya kreativitas sangat penting, ketika seseorang mendapatkan kreativitasnya, mereka cenderung menjadi percayaa dri, berani mengambil sebuah resiko, mandiri, selalu ingin tahu, antusias, dan spontan. Suprihatin (2017) mendefinisikan Kreativitas sebagai suatu proses mental individu yang melahirkan gagasan, proses, metode ataupun produk baru yang efektif yang bersifat imajinatif, fleksibel, suksesi, dan diskontinuitas, yang berdaya guna dalam berbagai bidang untuk pemecahan suatu masalah. Jadi kreativitas merupakan bagian dari usaha seseorang guru untuk mengembangkan pembelajaranya.(Wiyono, 2018)

Dalam memahami cara kreativitas bisa meningkatkan daya berpikir imajinatif, sebab kreativitas merupakan persyarat dari berpikir imajinatif. Akan tetapi di SD Negeri 2 Waha belum menunjukkan bahwa kreativitas belajar siswa belum optimal ditandai dengan beberapa permasalahan yang muncul dalam pembelajaran; peserta didik belum berani mengajukan pendapat untuk bertanya, materi Pendidikan Pancasila dan Kewarganegaraan yang diajarkan kurang dipahami oleh peserta didik, peserta didik kurang diberikan kesempatan untuk mengembangkan kreativitasnya, dan pada proses pembelajaran peserta didik kurang aktif. Selanjutnya proses pembelajaran di kelas menggunakan metode yang tidak bervariasi dan monoton pada satu arah, akibatnya suasana dalam kelas selalu terjadi keheningan sehingga kreativitas siswa sangat kurang. Dalam mengembangkan dan meningkatkan kreativitas belajar siswa pada Mata Pelajaran Pendidikan Pancasila dan kewarganegaraan dibutuhkan Metode baru dalam pembelajaran yaitu metode learning Start with A Question di Kelas V SD Negeri 2 Waha.

Pada penelitian sebelumnya telah banyak yang mengkaji tentang metode yang sama yaitu metode learning Star with A Question, namun mata pelajaran yang dikaji adalah mata pelajaran ilmu pengetahuan sosial, sehingga dalam penelitian ini fokus kajianya adalah tentang metode yang sama yaitu metode metode learning Star with A Question dengan mata pelajaran yang berbeda yaitu pendidikan kewarganegaraan, dengan tujuan untuk memberikan gambaran yang holistik tentang efektifitas dari metode metode learning Star withA Question dalam meningkatkan kreatifitas siswa pada beberapa mata pelajaran.

\section{METODE PENELITIAN}

Prosedur Tindakan Penelitian dengan menggunakan model spiral dari Kemis \& Mc Taggart (Dewi et al., 2016) yang terbagi atas tiga siklus dimana setiap siklusnya terdiri dari beberapa tindakan, dengan model siklus berulang berkelanjutan.Penelitan ini dilakukan dua kali pertemuan setiap siklus, adapun tahapannya yaitu perencanaan, pelaksanaan tindakan, observasi dan refleksi.Teknik pengumpulan data yang digunakan penelitian tindakan kelas; obsevasi, tes dan dokumentasi. Teknik analisis data mennggunakan rumus kreativitas siswa dan untuk menganlisis tingkat kreativitas siswa yaitu dengan cara menjumlah skor yang diperoleh siswa menjadi nilai siswa, denganmenggunakan rumus:Nilai $=\frac{\text { Skoryang diperoleh }}{\text { Skor maksimal }} x 100$. 
(Sudijono, 2011). Kemudian mengetahui nilai rata-rata kreativitas belajar yang diperoleh siswa, peneliti menggunakan rumus sebagai berikut:

$$
\mathrm{X}=\frac{\Sigma \mathrm{X}}{\Sigma \mathrm{N}}
$$

Keterangan:

$\mathrm{X}=$ Nilai rata-rata,

$\Sigma \mathrm{X}=$ Jumlah semua nilai siswa,

$\Sigma \mathrm{N} \quad=$ Jumlah siswa.

Sedangkan rumus untuk menghitung nikai presentase kreativitas belajar siswa sebagaiberikut: Kreativitas klasikal $=\frac{\text { Jumlah siswa yang tuntas }}{\text { Jumlah siswa seluruhnya }} \times 100 \%$.

Peneliti menggunakan kategori penilaian kreativitas yang dimodifikasi dari purwanto (Ngalim Purwanto, 2009) yang dapat dilihat sebagai berikut:

$\begin{array}{ll}90-100 & \text { Sangat Kreatif, } \\ 75-89 & \text { Kreatif } \\ 60-74 & \text { Cukup Kreatif, } \\ 45-59 & \text { Kurang Kreatif, } \\ <45 & \text { Sangat Kurang Kreatif (Ngalim Purwanto, 2009). }\end{array}$

\section{HASIL DAN PEMBAHASAN PENELITIAN}

Berdasarkan pengamatan kreativitas siswa dilakukan pada proses kegiatan belajar mengajar di siklus 1 pertemuan pertama berlangsung dengan mengamati kreativitas belajar siswa menunjukan bahwa tingkat kreativitas siswa yang mampu mencapai kategori kurang kreatif sebanyak 3 orang dan nilai rata-rata atau presentase sebesar 13,63\%, sedangkan siswa yang mencapai kategori sangat kurang kreatif sebanyak 19 . Tingkat kreativitas peserta didik masih dalam kategori sangat kurang kreatif. Karena tingkat kreativitas siswa dikatakan tuntas dalam kemampuan kreativitasnya apabila sudah memperoleh nilai >75 (dalam kategori kreatif dan sangat kreatif). Oleh karena itu penerapan metode pembelajaran Learning Start With A Question pada siklus 1 pertemuan pertama kreatvitas siswa belum meningkat.

Siklus 1 pertemuan kedua menunjukan kreativitas siswa dalam kategori cukup kreatif ada 13 orang dan rata-rata atau presentase sebesar $59.09 \%$, sedangkan kategori kurang kreatif ada 9 orang dan rata-rata atau presentase sebesar $40.90 \%$, oleh karena itu kreativitas peserta didik masih kategori kurang kreatif. Tingkat kreativitas peserta didik dikatakan tuntas dalam kemampuan kreativitasnya apabila Sudah memenuhi target nilai $>75$ (dalam kategori kreatif dan sangat kreatif). Oleh sebab itu penerapan metode pembelajaran Learning Start With A Question pada siklus I pertemuan kedua kreatvitas peserta didik belum meningkat dan di lanjutkan di siklus berikutnya.

Pada siklus 2 pertemuan pertama menunjukan jumlah nilai yang diperoleh oleh peserta didik sebanyak 1.455 dengan rata-rata 66,13 . Tingkat kreativitas yang diperoleh masih banyak peserta didik yang masuk kategori cukup kreatif dengan jumlah 16 orang, dan 2 orang peserta didik masih kurang kreatif, sedangkan 4 orang peserta didik masuk dalam kategori kreatif.

Maka dapat dikatakan bahwa tingkat kreativitas peserta didik masih dalam kategori cukup kreatif dengan presentase nilai $72,72 \%$. Kategori tingkat kreatif peserta didik dikatakan tuntas dalam kemampuan kreativitasnya apabila memperoleh nilai $>75$ (dalam kategori kreatif dan sangat kreatif). 


\section{Meningkatkan Kreativitas Belajar Siswa Melalui Metode Pembelajaran Learning Start With A Question}

di Sekolah Dasar - Kamarudin, Yana

DOI: https://doi.org/10.31004/edukatif.v3i1.284

Dengan demikian dapat dikatakan penerapan metode pembelajaran Learning Start With A Question pada siklus II pertemuan pertama kreatvitas peserta didik mulai meningkat.

Setelah diteruskan pada siklus 2 pertemuan kedua menunjukan bahwa jumlah nilai yang diperoleh oleh peserta didik sebanyak 1.765 dengan rata-rata 80,22\%. Dari jumlah siswa 22 orang ada 14 orang siswa masuk dalam kategori kreatif dan sangat kreatif 5 orang, sedangkan 3 orang siswa lainnya masuk kategori cukup kreatif, dimana sudah memenuhi tingkat kreativitas peserta didik. Pada siklus II pertemuan kedua kreatvitas siswa meningkat yaitu dalam kategoti kreatif dan sangat kreatif dengan nilai presentase 86,37 (kreatif).

Penelitian tindakan kelas untuk meningkatkan kreativitas belajar siswa di kelas V SD N 2 Waha pada mata pelajaran Pendidikan Kewarganegaraan. Penggunana metode yang kurang bervariasi merupakan salah satu masalah belajar dikelas V SD Negeri 2 Waha pada mata Pendidikan Kewarganegaraan sehingga peneliti ingin merubah keadaan agar dalam proses pembelajaran siswa lebih aktif dan meningkatkan kreativitas belajar siswa dengan menggunakan metode pembelajaran Learning Start With A Question di kelas V SDN2 Waha, peneliti melakukan penelitian dalam dua siklus pada penelitian ini. Dari hasil analisis data observasi yang dilakukan pada kondisi awal pra siklus tes kreativitas rata-rata siswa mendapatkan nilai dalam kategori sangat kurang kreatif dengan jumlah siswa 22 orang dan tes evaluasi belajar siswa hanya 3 orang yang mendapatkan nilai dalam kategori tuntas.

Siklus I dilakukan 2 kali pertemuan dengan tahap perencanaan, tahap pelaksanaan, observasi dan refleksi. Pada pertemuan pertama siklus I tes kreativitas siswa terdapat 3 orang mencapai kategori kurang kratif dengan nilai rata-rata atau presentase 13,63\% dan 19 orang lainya mencapai kategori sangat kurang kreatif. Kemudian pada pertemuan kedua siklus I tes kreativitas belajar siswa terdapat 9 orang siswa kategori kurang kreatif dan nilai rata-rata atau presentase 40,90\% dan 13 orang siswa dengan nilai rata-rata atau presentase $59,09 \%$ dalam kategori cukup kreatif, dan siklus I pertemuan kedua dilakukan tes evaluasi belajar siswa untuk mengukur sejauh mana pemahaman siswa terhadap materi yangsejauh mana telah diajarkan sejauh mana pada proses pembelajaran, serta diketahui bahwa hanya 5 orang siswa yang memiliki nilai 80 sampai 100 dan 17 orang lainya memiliki nilai 60, hal ini belum memenuhi persyaratan tuntas belajar yang di tentukan oleh kurikulum.

Selanjutnya pada kegiatan pembelajaran yang dilaksanakan oleh guru dengan menggunakan metode pembelajaran Leraning Start With A Question dalam meningkatkan kreativitas belajar siswa di kelas V SD Negeri 2 Waha dalam kategori cukup, dan masih ada beberapa aspek yang perlu di tingkatkan lagi. Jadi dilanjutkan dengan siklus II.

Pada hasil pengamatan siklus II yang dilaksanakan pada tes kreativitas belajar peserta didik menunjukan bahwa dari jumlah nilai keseluruhan 1.455 dengan nilai rata-rata 66,13\% dari total 22 siswa masih banyak siswa yang masuk dalam kategori cukup kreatif yaitu sebanyak 16 orang, dan 2 orang dalam kategori kurang kreatif, sedangkan 4 orang lainya dalam kategori kreatif dan kreativitas mulai meningkat. Dan pertemuan II siklus dua tingkat kreativitas belajar siswa diketahui bahwa sebanyak 1,765 dan nilai rata-rata $80,22 \%$ dari jumlah 22 orang siswa ada 14 siswa berkategori kreatif, 5 siswa berkategori sangat kreatif dan 3 siswa kategori cukup kreatif. Dan pada tes evaluasi belajar siswa siklus II meningkat dimana siswa mendapatkan nilai rata-rata $78,18 \%$ dan diketahui hanya 6 orang yang memiliki nilai 60 dan 16 orang lainnya dengan nilai 80 sampai dengan 100. Sedangkan pada kegiatan yang dikelola oleh pengajar menggunakan metode pembelajaran Learning Start With A Question dalam meningkatkan kreativitas belajar peserta didik di kelas V SD Negeri 2 Waha sudah dalam kategori baik dengan nilai presentase 78,57\%, dimana aspek pengelolaan pembelajaran sudah meningkat. 
218 Meningkatkan Kreativitas Belajar Siswa Melalui Metode Pembelajaran Learning Start With A Question di Sekolah Dasar - Kamarudin, Yana

DOI: https://doi.org/10.31004/edukatif.v3i1.284

\section{KESIMPULAN}

Berdasarkan pembahasan hasil penelitian penerapan metode pembelajaran Learning Start With A Question untuk meningkatkan kreativitas belajar siswa di kelas V SD Negeri 2 Waha pada mata pelajaran Pendidikan Pancasila dan Kewarganegaraan, hasilnya bahwa kreativitas belajar siswa dapat meningkat pada siklus II. Dimana pada siklus II pertemuan satu tes kreativitas siswa terdapat 16 dengan kategori cukup kreatif dan 2 orang siswa dalam kategori kurang kreatif, sedangkan 4 orang lainnya dalam kategori kreatif dari jumlah 22 orang siswa. Kemudian pada pertemuan kedua tingkat kreativitas belajar siswa ada 15 orang siswa masuk kategori kreatif, dan 5 orang siswa dalam kategori sangat kreatif, Sedangkan 2 orang lainnya masuk dalam kategori cukup kreatif. Dan pada tes evaluasi belajar siswapada siklus II meningkat dengan jumlah rata-rata $78,18 \%$. Jadi metode pembelajaran Learning Start With A Question dapat meningkatkan kreativitas pada pembelajaran Pendidikan Kewarganegaraan.

\section{SARAN}

Peneliti menyarankan kepada peserta didik agar selalu mempertahankan peningkatan kreativitasnya dalam proses pembelajaran dan mendengarkan arahan guru dengan serius saat memberikan pengarahan tentang pembelajaran Learning Start With a Question hal ini sangat diperlukan dukungan guru di sekolah yaitu untuk lebih memperhatikan kemampuan kreativitas yang dimiliki oleh siswa.

\section{DAFTAR PUSTAKA}

Astriani, C. (2018). Jurnal PPKn Penelitian dan Pemikiran Pancasila dan Kewaranegaraan. Jurnal PPKn, $6(1)$.

Dewi, R. R., Sujana, E., \& Anang, A. (2016). Performa pertumbuhan puyuh (coturnix-coturnix japonica) petelur jantan hasil persilangan warna bulu hitam dan coklat umur 0-7 minggu di pusat pembibitan puyuh. Media Peternakan.

Fajarwati, V. Y. (2011). Pengembangan Media Pembelajaran Berbasis Mobile Learning pada Materi Pengenalan Teknologi Informasi dan Komunikasi untuk Siswa Kelas VII SMP Negeri 3 Malang. In SKRIPSI Jurusan Teknik Elektro - Fakultas Teknik UM.

Firdaus, A. M. (2018). Efektivitas Pembelajaran Matematika melalui Metode Question Student Have (QSH) Setting Kooperatif. MAJAMATH: Jurnal Matematika Dan Pendidikan Matematika. https://doi.org/10.36815/majamath.v1i1.115

Istiningsih, S., Sri Widari, N. K., \& Hasanah, N. (2018). Efektivitas Teknik Mangkuk Ikan Atau Akuarium (Fish Bowl) Untuk Meningkatkan Hasil Belajar Ips Pada Siswa Kelas V A Sdn 16 Cakranegara Tahun Pelajaran 2016/2017. JKKP (Jurnal Kesejahteraan Keluarga Dan Pendidikan). https://doi.org/10.21009/jkkp.051.08

Kasyadi, Y., Kresnadi, H., \& Sugiyono. (2013). Peningkatan Hasil Belajar Siswa Pada Pembelajaran Ilmu Pengtahuan Alam Menggunakan Tipe Jigsaw. 1-12.

Maftuh, B. (2008). Internalisasi Nilai-Nilai Pancasila dan Nasionalisme Melalui Pendidikan Kewarganegaraan. Educationist.

Ngalim Purwanto. (2009). Prinsip-prinsip dan Teknik Evaluasi Pengajaran. In PT Remaja Rosdakarya.

Pane, A., \& Darwis Dasopang, M. (2017). Belajar dan Pembelajaran. Fitrah:Jurnal Kajian Ilmu-Ilmu Keislaman. https://doi.org/10.24952/fitrah.v3i2.945

Putra, T. T., Irwan, \& Vionanda, D. (2012). Pembelajaran berbasis masalah. Jurnal Pendidikan Matematika.

Rusman, D. . 2013. (2013). Pembelajaran Berbasis Tekhnologi Informasi Dan Komunikasi. Rajawali Pers: 
219 Meningkatkan Kreativitas Belajar Siswa Melalui Metode Pembelajaran Learning Start With A Question di Sekolah Dasar-Kamarudin, Yana

DOI: https://doi.org/10.31004/edukatif.v3i1.284

Depok Berdasarkan.

Slameto. (2014). Developing Critical Thinking Skills through School Teacher Training "Training and Development Personnel" Model and Their Determinants of Success. International Journal of Information and Education Technology. https://doi.org/10.7763/ijiet.2014.v4.390

Sudijono, A. (2011). Pengantar Statistik Pendidikan. In Anas Sudijono.

Suharsimi;, A. (2013). Dasar-Dasar Evaluasi Pendidikan. In Jakarta: Bumi Aksara.

Wiyono, T. (2018). Pengaruh Motivasi Siswa dan Kreativitas Belajar Terhadap Hasil Belajar PKn Siswa. Citizenship Jurnal Pancasila Dan Kewarganegaraan. https://doi.org/10.25273/citizenship.v6i2.3115 